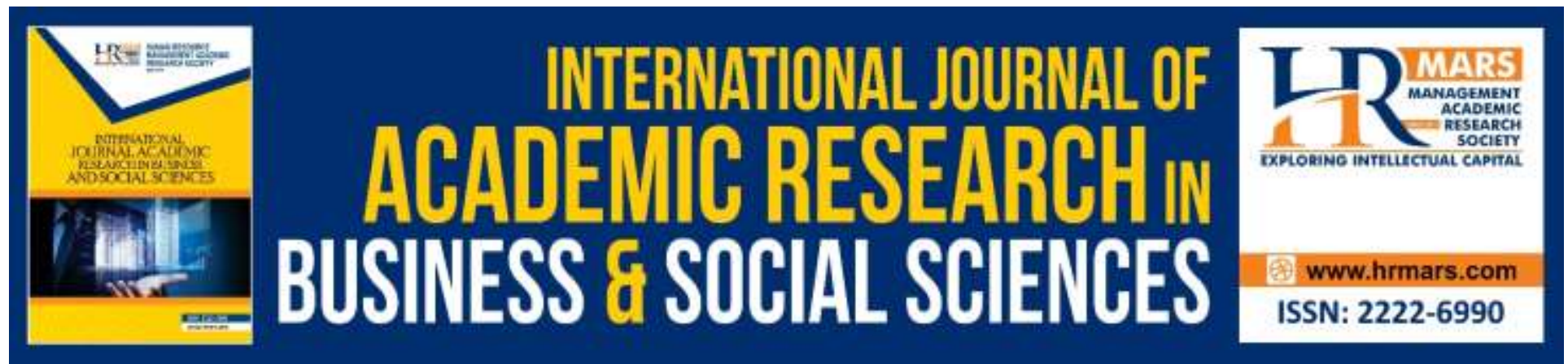

\title{
Measuring Value at Risk for Kijang Emas Investment using Historical Simulation Approach
}

Farah Azaliney Mohd Amin, Nurulhazwan Izmi Othman, Mohamad Khairil Amri Khairuddin and Muhammad Haikal Muhaimin Hazahar

To Link this Article: http://dx.doi.org/10.6007/IJARBSS/v9-i9/7003

DOI: $10.6007 /$ IJARBSS/v9-i9/7003

Received: 04 August 2019, Revised: 27 August 2019, Accepted: 06 September 2019

Published Online: 28 September 2019

In-Text Citation: (Amin et al., 2019)

To Cite this Article: Amin, F. A. M., Othman, N. I., Khairuddin, M. K. A., \& Hazahar, M. H. M. (2019). Measuring Value at Risk for Kijang Emas Investment using Historical Simulation Approach. International Journal of Academic Research in Business and Social Sciences, 9(9), 1363-1370.

Copyright: (C) 2019 The Author(s)

Published by Human Resource Management Academic Research Society (www.hrmars.com)

This article is published under the Creative Commons Attribution (CC BY 4.0) license. Anyone may reproduce, distribute, translate and create derivative works of this article (for both commercial and non-commercial purposes), subject to full attribution to the original publication and authors. The full terms of this license may be seen

at: http://creativecommons.org/licences/by/4.0/legalcode

Vol. 9, No. 9, 2019, Pg. 1363 - 1370

http://hrmars.com/index.php/pages/detail/IJARBSS

JOURNAL HOMEPAGE

Full Terms \& Conditions of access and use can be found at http://hrmars.com/index.php/pages/detail/publication-ethics 


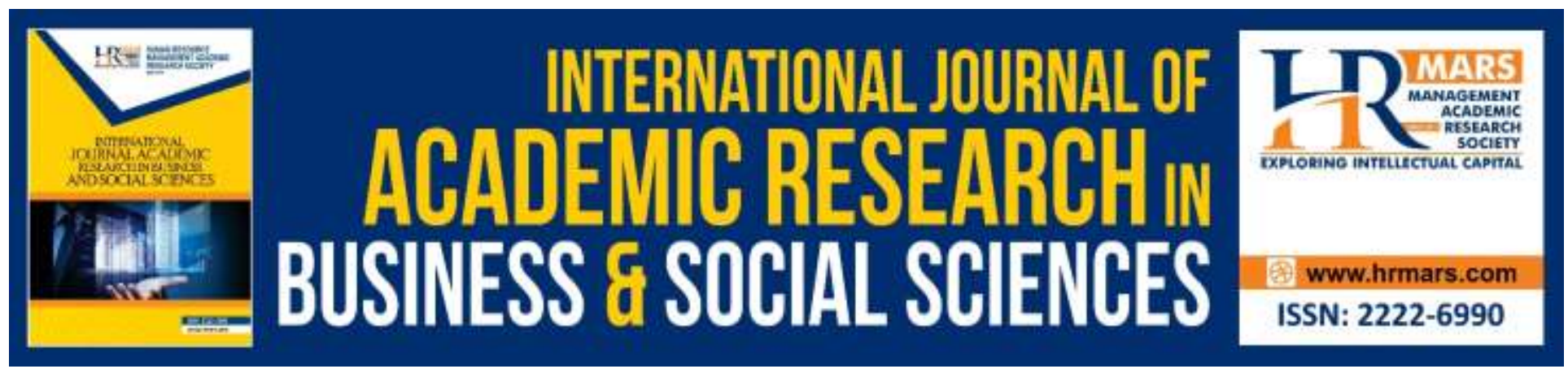

\title{
Measuring Value at Risk for Kijang Emas Investment using Historical Simulation Approach
}

\author{
Farah Azaliney Mohd Amin, Nurulhazwan Izmi Othman, \\ Mohamad Khairil Amri Khairuddin and Muhammad Haikal \\ Muhaimin Hazahar
}

Faculty of Computer and Mathematical Sciences, Universiti Teknologi MARA Cawangan Negeri

Sembilan, Kampus Seremban 3, 70300, Seremban, Negeri Sembilan, Malaysia

\begin{abstract}
The main objective of this study is to evaluate the performance of Value at Risk using Historical Simulation method for Kijang Emas investment, the official gold bullion coin of Malaysia. Previously, a common investor using variance or standard deviation which simply measures variation in risk. However, majority of the investors fail to relate it with the return of investment because downside risk is not being quantified in monetary terms. Thus, the Value at Risk (VaR) concept has been introduced to estimates the loss likely to be suffered by the investor with the certain level of probability express in any chosen currency such as Malaysia Ringgit, dollar, baht, etc. Result show that VaR concept is successfully been implemented and Historical Simulation method proven to accurately estimate the maximum potential loss under normal market condition. Therefore, domestic investors are recommended to use VaR for decision making purposes about investment in Kijang Emas.
\end{abstract}

Keywords: Value at Risk, Historical Simulation, Kijang Emas, Gold Investment.

\section{Introduction}

The domestic financial market situation have a direct relationship with the current state of the world economy. For example, the Asian financial crisis in 1997/1998 have resulted in economic instability in the region, particularly in Southeast Asia. Malaysia was also affected from adverse impacts such as currency devaluation, stock market and other assets prices decline as well as a sharp increase in private debt. Due to the crisis, Tun Dr. Mahathir Mohamad, the Prime Minister of Malaysia had proposed the use of gold especially in international trade (News Strait Times, 2001). In July 2011, Malaysia is the 12th country in the world to issue its own gold bullion coins known as Kijang Emas by the Bank Negara Malaysia (BNM).

A study conducted by Ibrahim (2012); Khalid, Islam \& Ahmed (2019) proved that gold prices in Malaysia are more stable and safe compared to other commodities or investments, especially stocks. Other research findings also show the ability of gold to serve as a safe haven or a hedge 
asset since it provides protection against losses during extreme market shocks differs from other assets (Bayram, Abdullah \& Meera, 2017; Baur \& Lucey, 2010; Baur \& McDermott, 2010). For example, during the global financial and economic crisis that started in 2007 the gold price experienced an intense increase while other assets (in particular stock prices) exhibited losses (Beckmann, Berger \& Czudaj, 2015; Alzgool (2019); Muhammad, Saoula, Issa \& Ahmed (2019). Since then, investors have begun to be interested in investing in gold as one of their alternative investment asset.

Previously, many studies have been using variance or standard deviation as risk measures in portfolio optimisation (Harlow, 1991; Nawrocki, 1991; Grootveld \& Hallerbach, 1999; Sing \& Ong, 2000). However, these approaches do not match investors' perception towards risk because it also penalize the upside deviation (profit) which is desirable for investors (Jamaan, Lam \& Isa, 2011). Thus, this study focus to measure only the downside risk to overcome the deficiencies of previous risk measures.

Value at Risk is being defined as the maximum amount an investor may lose over a given time period with a given probability represented by the following formula

$$
V a R=\alpha \sigma P_{0}
$$

where $\alpha$ is the level of significance in standard normal curve that corresponds to $(1-c)$ if $c$ is the selected confidence level, $\sigma$ denotes the standard deviation and $P_{0}$ denotes the total investment (Jorion, 2001). Finally, this study aim to evaluate the accuracy of measuring Value at Risk of Kijang Emas investment using Historical Simulation method at 95\% confidence level.

\section{Methodology}

Historical Simulation method is the most widely implemented and relatively simple to deploy based on the data collected (Linsmeier \& Pearson, 2000). The essence of this method is based on the underlying assumption that the near future will be sufficiently similar to the recent past for us to be able to use the data from the recent past to forecast the risk in the near future (Abad, P. et.al, 2013). Thus, Historical Simulation involves using past historical data as a guide to estimate what might happen in the future. However, this method cannot be applied if some assets having insufficient set of data.

Often Historical Simulation is also called non-parametric method because it does not rely on a particular assumed statistical distribution. Hence, it eliminates the need to estimate parameters such as means and standard deviation, as they are implicit in the data (Kiohos \& Dimopolous, 2004).

The following are the steps used to estimate monthly Value at Risk (VaR) at 95\% confidence level for Kijang Emas investment by using Historical Simulation: 


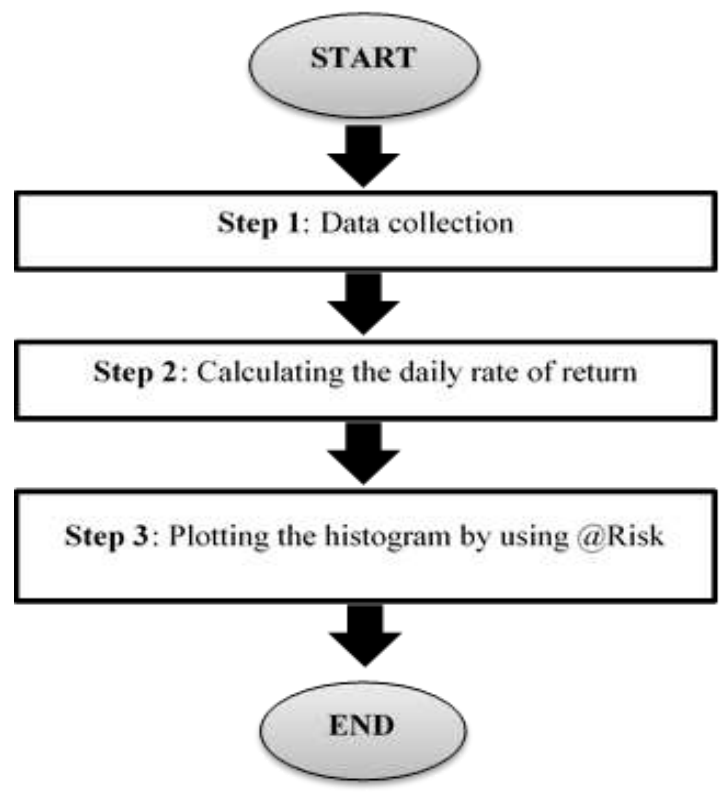

Figure 1. The flowchart to calculate VaR using Historical Simulation.

\section{Step 1: Data collection.}

The historical data of daily trading prices for Kijang Emas is collected from the central bank of Malaysia, Bank Negara Malaysia website. The data is collected between September,2016 and August,2017. RM is the notation for the Malaysian Ringgit.

\section{Step 2: Calculate the Rate of Return}

According to Gruber, Elton, Brown and Goetzmann (1991), the historical return at time- $t, R_{t}$ by using the following formula:

$$
R_{t}=\ln \left[\frac{P_{t}}{P_{t-1}}\right]
$$

where $P_{t}$ denotes the trading price at time- $t$ and $P_{t-1}$ denotes the trading price at time $t-1$.

\section{Step 3: Plot the Histogram}

As an example, Figure 2 below show the histogram using the historical distribution of returns in October,2016 is obtained to simulate a series of potential future returns in November,2016 and then sorted. Observed that, to determine VaR correspond to $95 \%$ confidence level, the focus will be on the left tail which is the lowest $5 \%$ percentiles in the distribution. This study used @RISK software is an add-in to Microsoft Excel that automatically calculate VaR based on the selected confidence level. 


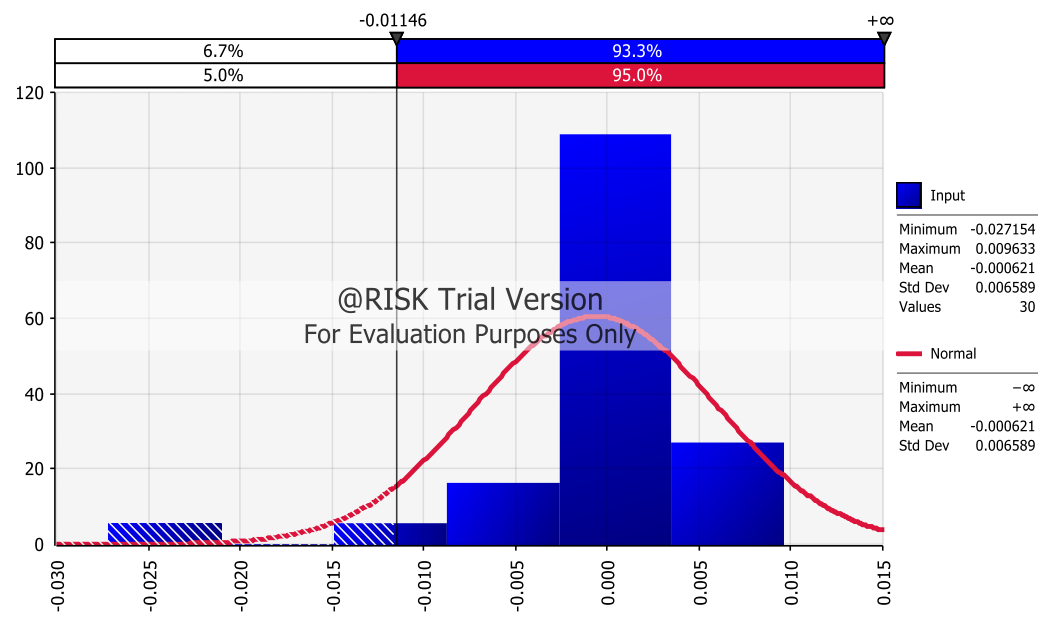

Figure 2. Histogram using historical rate of return in October, 2016

From Figure 2 above, the VaR at $95 \%$ confidence level is -0.01146 . Alternatively, VaR can also be expressed in any monetary terms using Equation (1). Hence, VaR in Malaysia Ringgit is 0.01146 $x$ RM $80,000=R M 916.80$. Notice that, we drop the minus sign because VaR is referred to as a loss. Therefore, in normal market conditions the maximum loss that expected to be incurred in November,2016 at 95\% confidence level is RM 916.80.

\section{Step 4: Mean Absolute Percentage Error (MAPE)}

The MAPE usually express accuracy as a percentage and is calculated as follows:

$$
M A P E=\left[\frac{1}{n} \sum_{i=1}^{n} \frac{\left|a_{i}-p_{i}\right|}{\left|a_{i}\right|}\right] \mathrm{X} 100
$$

where $n$ equal to the total number of unit trust fund involved, $a_{i}$ and $p_{i}$ are actual and predicted values, respectively.

The scale of the judgement of forecasting the accuracy by using MAPE is illustrated in Table 2 below. The approach with a lower MAPE is expected to produce better results.

Table 1. MAPE

\begin{tabular}{cc}
\hline MAPE & Accuracy \\
\hline$<10 \%$ & Highly accurate \\
$11 \%-20 \%$ & Good forecast \\
$21 \%-50 \%$ & Reasonable forecast \\
$>51 \%$ & Inaccurate forecast \\
\hline
\end{tabular}




\section{Results and Discussions}

Figures 3 below shows a graphical summary of VaR using Historical simulation and the actual VaR for each consecutive month from September, 2016 until August, 2017.

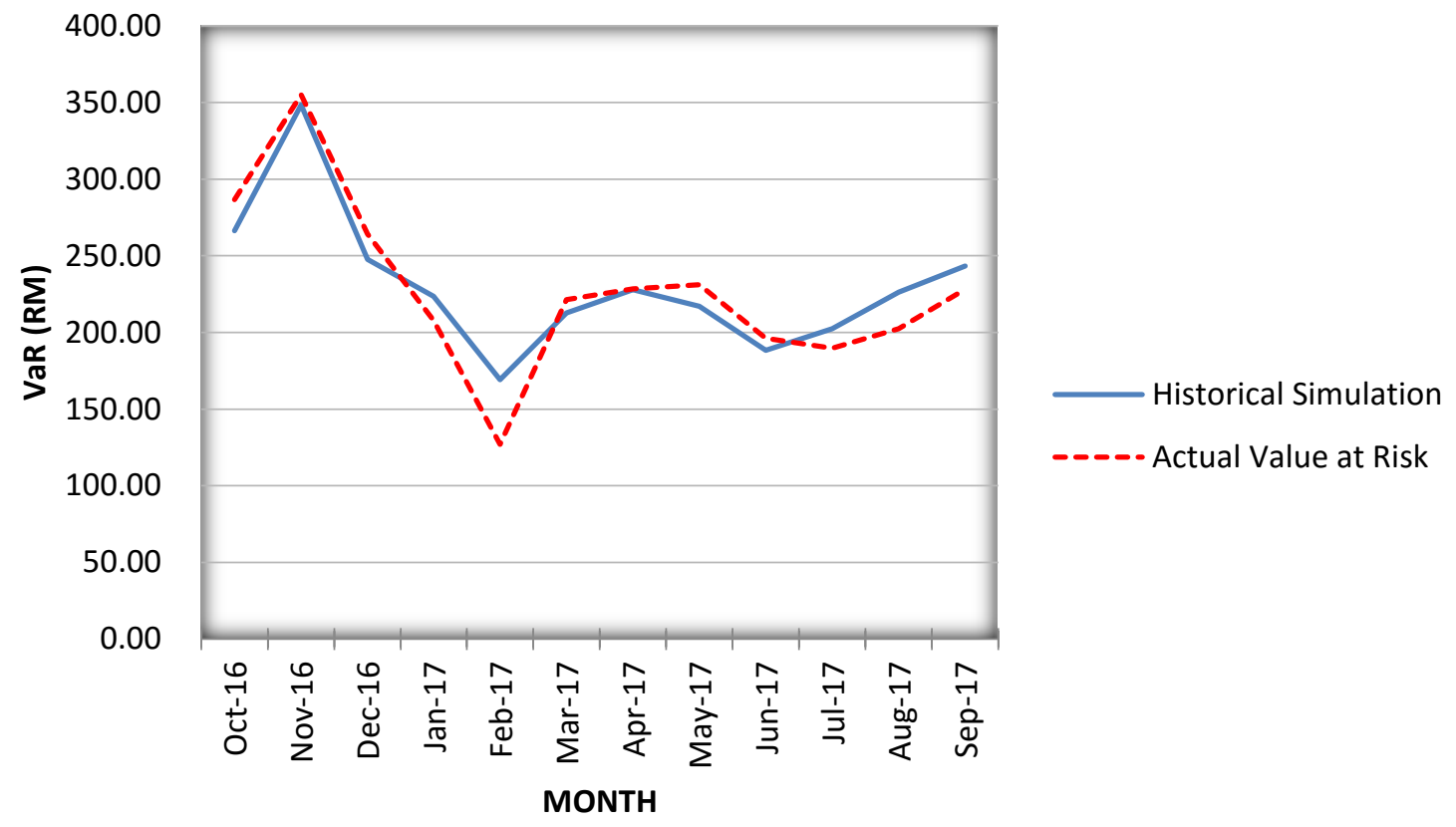

Figure 3. Comparison between Historical Simulation and actual VaR

Figure 3 above, the behavior of Historical Simulation and actual VaR move in symmetry along the one-year period observed. Indirectly, it will definitely help the investors in monitoring the trend for overall performance of VaR for the Kijang Emas investment. Clearly, the highest VaR indicate maximum downside risk occurs during November, 2016 and the lowest VaR is on February, 2017. We can expect that the trend remain the same in the future since it is consistent with the underlying assumption in Historical Simulation that historical returns is a good proxy for the future returns. To further evaluate the performances of Historical Simulation method, the Mean Absolute Percentage Error (MAPE) is calculated using Equation (3). The average MAPE for Historical Simulation is $7.94 \%$. Hence, Historical Simulation method is considered highly accurate in measuring VaR since the average MAPE value are less than 10\% using Table 1 above.

\section{Conclusion}

In this study, Value at Risk approach has successfully apply to measure market risk for Malaysia's gold bullion coin, the Kijang Emas. The greatest advantages of VaR is the ability to quantify the downside risk in a single, easy to understand by putting a value on risk to help investor decide whether a risk is worth taking. Although there are various methods which produces $\mathrm{VaR}$ measures, this study choose to implement Historical Simulation because the availability of complete historical data of daily trading prices for Kijang Emas and it is the simplest way of estimating Value at Risk. Results of the study revealed that Historical Simulation is highly accurate method to compute monthly VaR during the one-year period observed. Hence, the main 
capability of Historical Simulation is that it captures all recent market crashes to guide investor in making accurate investment decisions based on their objectives and risk tolerance.

Although Value at Risk approach is well-known in risk management, VaR has its limitations. For example, an assumption in Historical Simulation that the past represents the immediate future which is not always true. Thus, VaR measures may be acceptable for short terms horizon. It may provide less accurate risk for long terms investments because the future financial markets can be exposed to changes in interest rates and monetary policies, etc. Finally, it should also be noted that VaR only measure market risk under normal market conditions. In times of great volatility such as war, it may also not be reliable.

\section{Corresponding Author}

Farah Azaliney Mohd Amin

Department of Mathematics

Faculty of Computer and Mathematical Sciences

Universiti Teknologi MARA Cawangan Negeri Sembilan, Kampus Seremban 3, 70300, Seremban,

Negeri Sembilan, Malaysia

Email: farah525@uitm.edu.my

\section{References}

Abad, P., Benito, S., \& Lopez, C. (2014). A Comprehensive Review of Value at Risk Methodologies. The Spanish Review of Financial Economics, 12, 15-32.

Alzgool, M. (2019). Nexus between Green HRM and Green Management towards Fostering Green Values. Management Science Letters, 9(12), 2073-2082.

Baur, D. G., \& Lucey, B. M. (2010). Is Gold a Hedge or a Safe Haven? An Analysis of Stocks, Bonds and Gold. The Financial Review, 45, 217-229.

Baur, D. G., \& McDermott, T. K. (2010). Is Gold a Safe Haven? International Evidence. Journal of Banking and Finance, 34, 1886-1898.

Bayram, K., Abdullah, A., \& Meera, A. K. M. (2017). Financial Market Risk and Gold Investment in an Emerging Market: The Case of Turkey. Journal of Islamic Finance (Special Issue), 091099.

Beckmann, J., Berger, T., \& Czudaj, R. (2015). Does Gold Act as a Hedge or a Safe Haven for Stocks? A Smooth Transition Approach. Economic Modelling, 48, 16-24.

Grootveld, H., \& Hallerbach, W. (1999). Variance vs downside risk: Is there really that much difference?. European Journal of Operational Research, 114(2), 304-319.

Gruber, M. J., Elton, E. J., Brown, S. J., \& Goetzmann, W. N. (1991). Modern Portfolio Theory and Investment Analysis. Singapore: John Wiley \& Sons, Inc.

Harlow, W. V. (1991). Asset allocation in a downside-risk framework. Financial Analysts Journal, 28-40

Ibrahim, M. H. (2012). Financial Market Risk and Gold Investment in an Emerging Market: The Case of Malaysia. International Journal of Islamic and Middle Eastern Finance and Management, 5(1): 25-34. 
Jamaan, S. H., Weng, H. L., \& Isa, Z. (2011). Different Downside Risk Approaches in Portfolio Optimisation. Journal of Quality Measurement and Analysis 7(1), 77-84.

Jorion, P. (2001). Value at Risk: The New Benchmark for Managing Financial Risk. Business and Economics, 1-24.

Khalid, N., Islam, D. M. Z., \& Ahmed, M. R. M. (2019). Sentrepreneurial Training and Organizational Performance: Implications for Future. Humanities \& Social Sciences Reviews, 7(2), 590-593.

Kiohos, A., \& Dimopoulos, A. (2007). Estimation Portfolio VaR with Three Different Methods: Financial Institution Risk Management Approach. Journal of Economics and Business, 54(2), 59-83.

Linsmeier, T. J., \& Pearson, N. D. (2000). Value at Risk. Financial Analysts Journal, 56(2), 47-67.

Muhammad, K., Saoula, O., Issa, M., \& Ahmed, U. (2019). Contract Management and Performance Characteristics: An Empirical and Managerial Implication for Indonesia. Management Science Letters, 9(8), 1289-1298.

Nawrocki D. N. (1999). A Brief History of Downside Risk Measures. Journal of Investing, 8, 9-25. News Strait Times, 2001. Standardize Practices in Islamic Banking, June 26.

Sing, T. F., \& Ong, S. E. (2000). Asset Allocation in a Downside Risk Framework. Journal of Real Estate Portfolio Management, 6(3), 213-223. 